\title{
Reservoir characteristics of intracontinental carbonate ramp deposits- Upper Muschelkalk, Middle Triassic, NE Netherlands
}

\author{
M. C. Pöppelreiter ${ }^{1,2}$, A. Simone ${ }^{1}$ \& G. Hoetz ${ }^{1}$ \\ ${ }^{1}$ Nederlandse Aardolie Maatschapij, Schepersmaat 2, P.O. Box 28000, 9400 HH Assen, \\ the Netherlands. Present address: ${ }^{2}$ Shell, SEPTAR, 3737 Bellaire Blvd., Houston, Texas, \\ 77025, U.S.A. e-mail: michael.poppelreiter@shell.com
}

Manuscript submitted: September 2002; accepted: September 2003

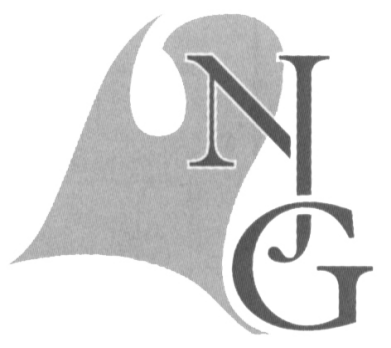

\begin{abstract}
The Upper Muschelkalk is an unusual reservoir in NW Europe, producing only in the Coevorden Muschelkalk field, onshore the Netherlands. Origin and nature of the gas producing intervals were poorly known. The objective of the paper is to provide a comprehensive description of facies, cyclicity and petrophysical characteristics. From this description a depositional and sequence stratigraphic model is proposed, which explains why there is gas production only from certain intervals of the sequence. Our investigation is based on seismic, core and open hole log data. It indicates that the reservoir consists of dolomites, which are either muddy lagoonal to sabkha, or grainy backshoal deposits. The best reservoir quality is encountered in peloidal-oolitic packstones to grainstones. These represent storm-dominated backshoal deposits and constitute the inner part of a homoclinal carbonate ramp. The succession shows a conspicuous hierarchical cyclicity. Porous backshoal deposits form during maximum transgression and early regression. However permeable, gas producing backshoal deposits only occur in the upper 15 to $20 \mathrm{~m}$, which forms the large-scale regressive hemi-cycle of the Upper Muschelkalk. Better reservoir quality in the upper hemi-cycle is due to changes in grain type and early diagenesis. The investigation might serve as calibration point for further exploring the Upper Muschelkalk reservoir and its facies pattern in the NW European basin.
\end{abstract}

Keywords: Germanic basin, Triassic, Upper Muschelkalk, NE-Netherlands, homoclinal ramp, storm-dominated, cyclicity, early diagenesis.

\section{Introduction}

The Upper Muschelkalk (Middle Triassic) is a unique play in NW Europe. The only gas producing reservoir of this age is the Coevorden Muschelkalk field, onshore the Netherlands, overlying the main producing reservoir units Carboniferous sandstones and Zechstein carbonates (Fig. 1).

Recently a number of Upper Muschelkalk prospects were identified. This triggered an integrated reservoir characterisation study based on detailed core descriptions, high-resolution sequence stratigraphy, open hole log characterization and seismic interpretation.

The objective of the present paper is a comprehensive description of facies, cyclicity and petrophysical characteristics of the Upper Muschelkalk. From this description a depositional and sequence stratigraphic model is proposed, which can explain gas production limited to certain reservoir intervals.

The Coevorden Muschelkalk field is located in the northeast part of the Netherlands, close to the DutchGerman border (Fig. 1). The field is a fault-bounded and dip-closed structure located in a NNW-SSE striking inverted graben (Figs $1 \& 3$ ). Argillaceousevaporitic Keuper deposits provide the top seal of the reservoir. Laterally the Upper Muschelkalk is sealed by major strike-slip faults, which offset the reservoir rocks against Middle Muschelkalk evaporites (Hoetz et al., 2001). The Upper Muschelkalk reservoir is 35 to $50 \mathrm{~m}$ thick (Mabillard et al., 1989) and consists of dolomites and dolomitic shales. It comprises muddy, 


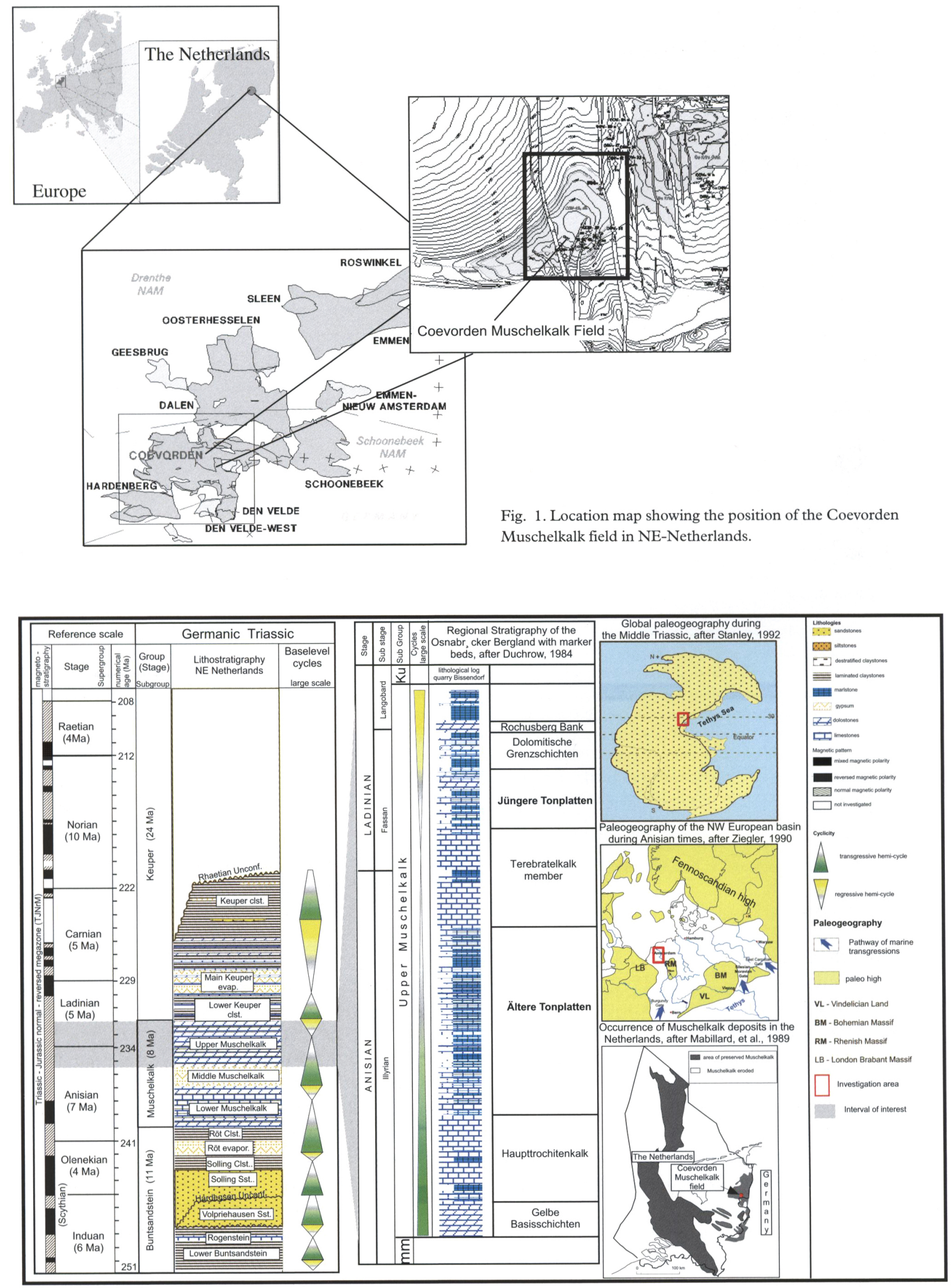

Fig. 2. Stratigraphy, paleogeography and occurrence of the Upper Muschelkalk. Modified after Aigner \& Bachmann (1992), Duchrow, (1984), Aigner et al. (1999), Hagdorn et al. (1991). 


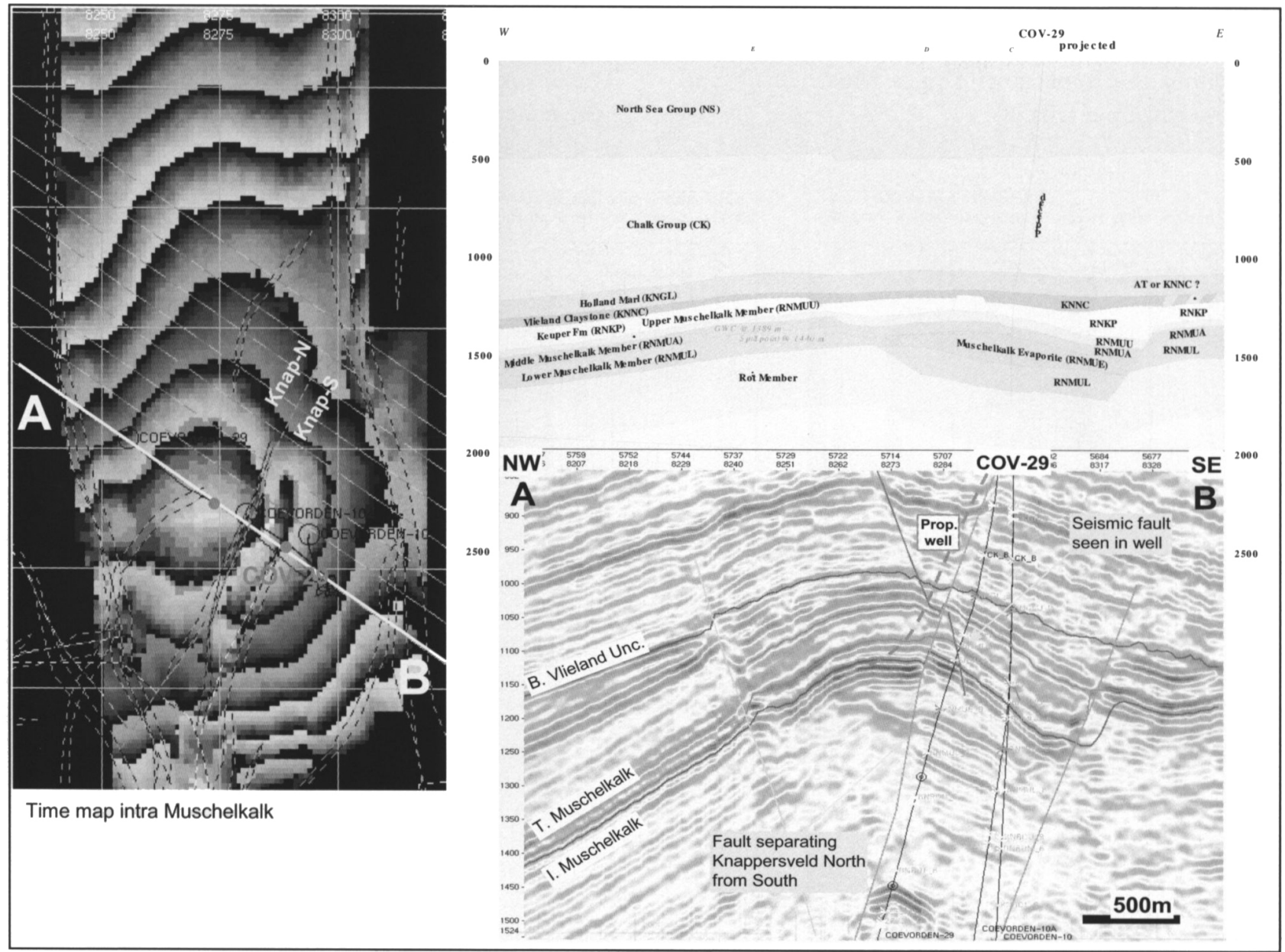

Fig. 3. Map view and cross sections of the Coevorden Muschelkalk field showing the fault and dip closed structure in an inverted $\mathrm{N}-\mathrm{S}$ running graben

low permeable deposits intercalated with grainy, peloidal-oolitic, better permeable deposits. The field was charged by the underlying Carboniferous coal measures.

\section{Geological Setting}

The Upper Muschelkalk Formation was deposited in the intracratonic NW European basin during the Middle Triassic. The basin was located about $30^{\circ} \mathrm{N}$ of the equator during this period of time (Ziegler, 1990; Dercourt et al., 1993), (Fig. 2). The NW European basin experienced a hurricane-dominated, subtropical climate (Szulc, 1999) with seasonal storms (Marsaglia \& de Vries Klein, 1983) (Fig. 2). The Upper Muschelkalk deposits were laid down in a shallow epeiric sea, which covered large parts of Central Europe during the Middle Triassic (Ziegler, 1990). The sea was connected to the Tethys Ocean by narrow gates (Fig. 2) through which seawater entered the basin. Limited clastic input was derived mainly from the Fennoscandian High. This basin setting is reflected in a strong facies asymmetry with a clastic domi- nated northern part and a carbonate-dominate south part. Four main facies belts can be distinguished on a basin-wide scale:

i) Marly limestone-dominated basin center,

ii) Limestone-dominated shoal facies belt,

iii) Dolomite-dominated backshoal and lagoonal facies belt,

iv) Clastic-dominated fringe facies belt around paleohighs (Aigner, 1985).

The depositional environment of the Upper Muschelkalk has been interpreted as storm - and tide-dominated carbonate ramp system based on extensive outcrop studies in Southern and Northern Germany (Aigner, 1985, Röhl, 1990, Gärtner, 1993, Schauer \& Aigner 1997). Outcrop studies also revealed the Upper Muschelkalk was deposited during a large-scale transgressive-regressive cycle (Aigner, 1985, Hagdorn, et al., 1987, Röhl, 1990) extending over the interval between the base of the Middle Muschelkalk to the top of the Upper Muschelkalk (Fig. 2). Maximum transgression occurs in the upper part of the Upper Muschelkalk (Aigner \& Bachmann, 1992, Aigner et al, 1999). Subsequently, during overall regression, 
siliciclastic material derived chiefly from the Fennoscandian High gradually replaced the carbonates within the uppermost Upper Muschelkalk and the Lower Keuper (Fig. 2).

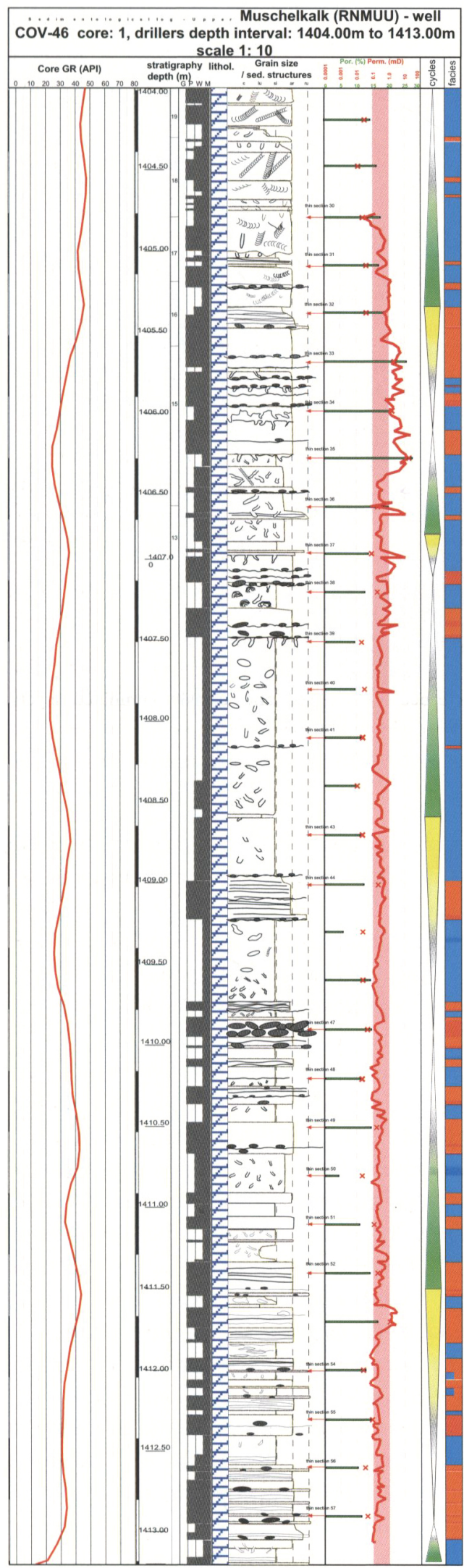

\section{Data Base}

The investigations are based on seismic, core and open-hole log data. Seismic interpretation makes use of a 3D PSDM volume of good to very good data

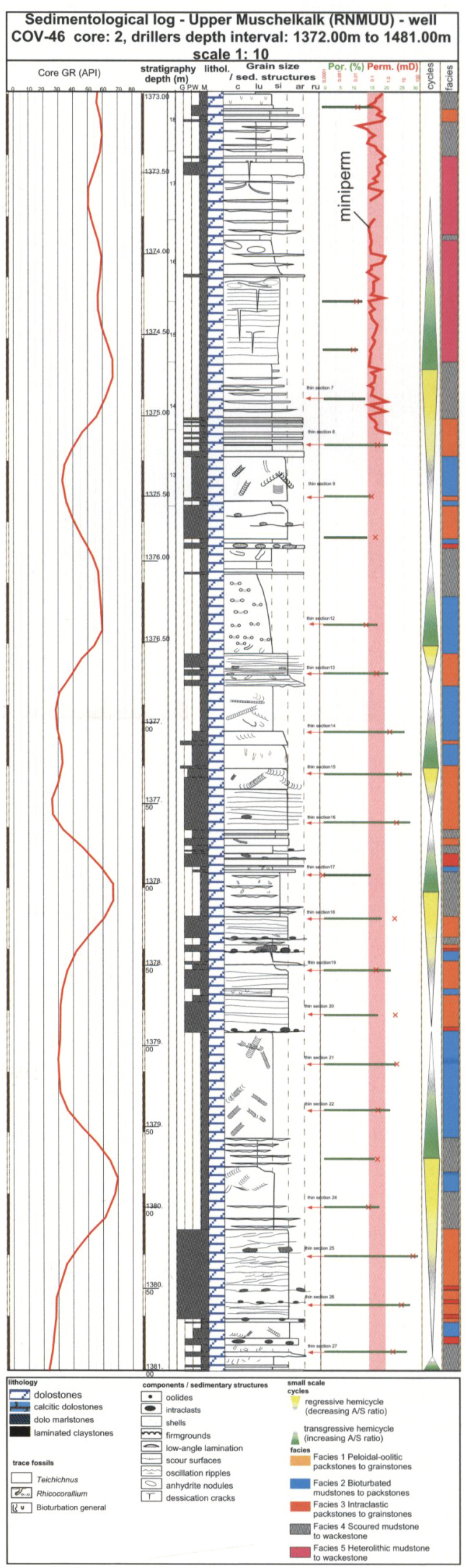

Fig. 4. Detailed sedimentological $\log$ of two cores from the Upper Muschelkalk in the NE Netherlands. Note the rapid vertical facies changes and the limited resolution of the core GR.

The position of the cores in well Coevorden- 46 is shown in Fig. 11. 


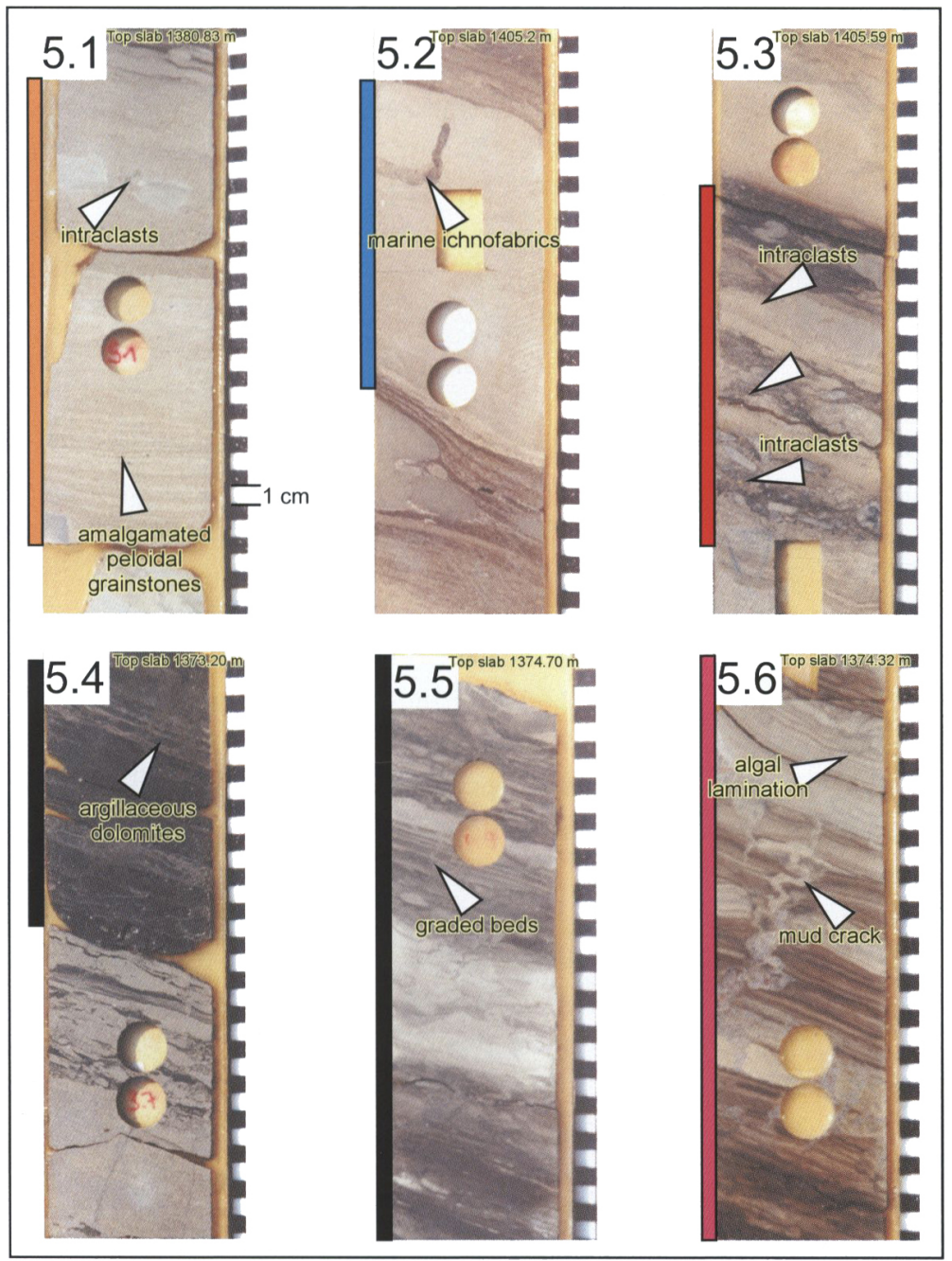

Fig. 5-1. Facies 1, Peloidal-oolitic packstone to grainstones. Shown are amalgamated storm beds with angular intraclast. These beds cover an erosive base and show low-angle lamination and oscillation ripples. The beds are covered by dark bioturbated to laminated mudstones. Coevorden-46, $1380.90 \mathrm{~m}, \Phi$ $=27.3 \%, \mathrm{Kh}=9.6 \mathrm{mD}$.

Fig. 5-2. Facies 2, Bioturbated mudstones to wackestones. The picture shows the wackestones with Rhizocorallium burrow testifying open marine conditions in these deposits. Coevorden-46, $1405.50 \mathrm{~m}, \Phi=16.5 \%, \mathrm{Kh}=0.06 \mathrm{mD}$

Fig. 5-3. Facies 3, Intraclast packstones to grainstones. Several stacked intraclastic layers, including bored intraclasts, point to amalgamated storm beds. These intraclast beds have poor reservoir quality. COV-46, $1405.7 \mathrm{~m}, \Phi=17.4 \%, \mathrm{Kh}=0.07 \mathrm{mD}$.

Fig. 5-4. Facies 5, Scoured argillaceous mudstones to wackestones. The facies is comprised of thin grain-rich layers and marly bioturbated beds. These deposits probably represent distal storm-related washover deposits. Coevorden-46, $1374.50 \mathrm{~m}, \Phi=$ $14.6 \%, \mathrm{Kh}=0.02 \mathrm{mD}$.

Fig. 5-5. Facies 6, Heterolithic mudstones to wackestones. The scoured layers in places with small intraclasts are interbedded with muddy beds which show irregular, crinkly lamination probably related to algal lamination.

Coevorden-46, $1374.80 \mathrm{~m} \Phi=8.2 \%, \mathrm{Kh}=0.01$ $\mathrm{mD}$.

Fig. 5-6. Facies 6, Heterolithic mudstones to wackestones. These facies comprises thinly interbedded scoured and crinkly laminated layers. Note deformed desiccation cracks filled with early anhydrite. Coevorden-46, $1374.55 \mathrm{~m} \Phi=5.8 \%$, $\mathrm{Kh}=0.0001 \mathrm{mD}$. quality. Two spot cores from type well Coevorden- 46 are available, which are, to our knowledge, the only substantial cores of the Upper Muschelkalk in the Netherlands. $9 \mathrm{~m}$ of core are taken from the bottom part of the Upper Muschelkalk reservoir and $9 \mathrm{~m}$ are from the upper part. Description of these cores was supplemented by visits to the nearest outcrops, close to the German city of Osnabrück, some $150 \mathrm{~km}$ east of the Coevorden field.

A total of 55 porosity and permeability plug measurements from well Coevorden-46 are available together with 42 thin sections and core gamma ray measurements.

The petrophysical characterisation is based on standard open hole logs of eight wells including gamma ray (GR), density (DEN), neutron (CNL), and sonic (SON) logs. Two of these eight wells are currently producing, one of which has production logging tool (PLT) data.

\section{Investigation Methods}

Seismic interpretation was carried out at a 3D Pre-
Stack Depth Migration (PSDM) data set leading to a revised fault interpretation at Upper Muschelkalk level. Seismic attribute maps were generated to check for porosity variations. The available two spot cores were described sedimentologically and subdivided into facies, facies associations and cycles to support petrophysical evaluation. The existing lithostratigraphic subdivision (Pipping, 1999) was matched to the regional sequence-stratigraphic framework (Borkhataria, 2002). Small-scale cycles were identified and correlated. Core plugs were re-measured to evaluate permeability's below $0.8 \mathrm{mD}$, previously considered as non-permeable because of equipment limitations. Thin sections of all core plugs were classified with respect to facies and pore type. Mini-permeameter measurements were carried to capture small-scale permeability variations. Bulk mineral composition was determined from all available open hole logs to establish grain density as input for porosity calculation. Porosity was calculated from density and sonic logs. Log evaluation results were validated with core plug data. 


\section{Seismic Interpretation}

The upper limit of the Upper Muschelkalk carbonates with the overlying Keuper claystones marks an important change in acoustic impedance giving rise to one of the best-resolved reflector in the area of interest (Fig. 3). Identification of the seismic pick is corroborated by synthetic seismic traces based on open hole sonic and density logs (Hoetz et al., 2001). Using this reflector, a detailed fault interpretation was carried out. This was supported by horizon attribute analysis in particular dip, azimuth and illumination maps.

Thus faults with a throw of more than about $15 \mathrm{~m}$ were mapped out. This refinement of the fault interpretation indicated that the Coevorden Muschelkalk structure is likely compartmentalised in a larger northern (Knappersveld-North) and a smaller southern block (Knappersveld-South) (Fig. 3). The existing producing wells penetrated only the southern block and probably fail to drain the northern field block, if the separating fault is sealing. Attribute maps were also checked for changes indicative for reservoir quality variations without conclusive results.

Facies subdivision, reservoir characteristics and pore types
Two spot cores of well Coevorden-46 were investigated (Figs $4 \& 5.1$ to $5.6,6$ ), which consist entirely of dolomites and dolomitic shales. Porosity varies between 4.5 and $29 \%$ and permeability ranges from 0.0001 to $51 \mathrm{mD}$. The cores are subdivided into five lithofacies taking into account sedimentary structures, reservoir quality variations and wireline log response:

i) Facies 1, Peloidal-oolitic pack - to grainstone (Figs 5.1,6)

ii) Facies 2: Bioturbated mud - to packstone (Figs $5.2,6)$

iii) Facies 3: Intraclastic pack - to grainstone (Figs $5.3,6)$

iv) Facies 4: Scoured argillaceous mud - to wackestone (Figs 5.4,6)

v) Facies 5: Heterolithic mud - to wackestone (Figs $5.5,5.6,6)$

Facies 1 and 3 consist predominantly of millimeter to centimeter-scale graded beds with a sharp erosive base (Fig. 5). These graded beds show features such as low-angle lamination, micro-hummocks, oscillation ripples and intraclasts, imbricated in places (Figs $5.1,5.3)$. Skeletal material is conspicuously rare while peloids dominate. Based on sedimentary structures, components and regional knowledge Facies 1 and 3 are interpreted to represent high-energy backshoal

\begin{tabular}{|c|c|c|c|c|}
\hline Facies type, sketch & $\begin{array}{l}\text { Lithology, sedimentary structures, } \\
\text { fossils }\end{array}$ & Microfacies & Reservoir quality & Interpretation \\
\hline $\begin{array}{l}\text { Facies 1: Oolitic-peloidal } \\
\text { packstones to grainstones }\end{array}$ & \begin{tabular}{|l|} 
- yellow-gray dolomites \\
$-4 \mathrm{~cm}$ to $50 \mathrm{~cm}$ average $15 \mathrm{~cm}$ thick \\
- amalgamated graded beds, erosive base, \\
horizontally, low-angle, low-angle trough cross \\
bedding, micro-hummocks \\
- no or low degree of bioturbation \\
- below: facies 3,4 ; above: $2,3,4,5$
\end{tabular} & $\begin{array}{l}\text { components: peloids,ooids } \\
\text { (micritised), intraclasts, } \\
\text { skeletal components, } \\
\text { grapestones, } \\
\text { - cement: isopachous fringes }\end{array}$ & $\begin{array}{l}\text { - Phi }=12-29 \% \\
\text { - Kh }=0.14 \text { to } 51 \mathrm{mD} \\
\text { - Phi type: mouldic, } \\
\text { interparticle, intercrystalline }\end{array}$ & $\begin{array}{l}\text { - storm-dominated deposits } \\
\text { - backshoal washovers, } \\
\text { - shallow sub aquatic fair } \\
\text { weather wave base } \\
\text { - normal sea water } \\
\text { - inner ramp (peloidal) backshoal }\end{array}$ \\
\hline \begin{tabular}{|l|l|}
$\begin{array}{l}\text { Facies } 2 \text { Bioturbated } \\
\text { mudstones to packstones }\end{array}$ \\
see Fig. 5.2
\end{tabular} & $\begin{array}{l}\text { - yellow-gray dolomites } \\
-2 \mathrm{~cm} \text { to } 16 \mathrm{~cm} \text { average } 5 \mathrm{~cm} \text { thick } \\
\text { - relics of horizontal to low-angle lamination } \\
\text { - strong/complete bioturbation } \\
\text { (Rhizocorallium,Planolites) } \\
\text { - below: facies } 3,1 \text {; above: } 1,4,\end{array}$ & $\begin{array}{l}\text { - components: peloids, quartz, } \\
\text { skeletal components, } \\
\text { - cement: (sub)euhedral } \\
\text { dolomite crystals }\end{array}$ & $\begin{array}{l}\text { Phi: } 4.5-22 \% \text {, } \\
\text { Kh }=0.021 \text { to } 0.47 \mathrm{mD} \\
\text { Phi type: interparticle, } \\
\text { intercrystalline }\end{array}$ & $\begin{array}{l}\text { - bioturbated lagoon } \\
\text { - shallow subaquatic } \\
\text { - normal sea water } \\
\text { - inner ramp backshoal lagoon }\end{array}$ \\
\hline $\begin{array}{l}\text { Facies 3: Intraclastic } \\
\text { packstones to grainstones }\end{array}$ & $\begin{array}{l}\text { - yellow, light dark-gray (controlled by clasts) } \\
\text { dolomites } \\
-1 \mathrm{~cm} \text { to } 10 \mathrm{~cm} \text { average } 4 \mathrm{~cm} \text { thick } \\
\text { - graded, erosive base, clast supported, } \\
\text { imbrication, bored clasts, } \\
\text { - no bioturbation } \\
\text { - below: facies } 1,4,2 \text {; above: } 1\end{array}$ & $\begin{array}{l}\text { components: intraclasts, } \\
\text { peloids, ooids, skeletal } \\
\text { components, } \\
\text { cements: isopachous fringes, } \\
\text { subeuhedral dolomite crystals }\end{array}$ & $\begin{array}{l}\text { - Phi: } 10-22 \% \\
\text { - Kh }=0.05 \text { to } 0.12 \mathrm{mD} \\
\text { - Phi type: interparticle, } \\
\text { intercrystalline }\end{array}$ & $\begin{array}{l}\text { - storm-dominated deposits } \\
\text { - transgressive lags, base of } \\
\text { tempestites, max. energy facies } \\
\text { - SWB to FWWB } \\
\text { - normal sea water } \\
\text { - inner ramp }\end{array}$ \\
\hline $\begin{array}{l}\text { Facies } 5: \text { Scoured } \\
\text { marlstones to wakestones }\end{array}$ & $\begin{array}{l}\text { - dark gray with light gray scoured } \\
\text { marly dolomites } \\
-4 \mathrm{~cm} \text { to } 50 \mathrm{~cm} \text { average } 15 \mathrm{~cm} \text { thick } \\
\text { - horizontal lamination, scours and } \\
\text { millimeter-scale graded beds } \\
\text { - weak to medium bioturbation (Planolites) } \\
\text { - below: facies } 1,3 ; \text { above: } 6,2,3,1\end{array}$ & $\begin{array}{l}\text { components: peloids, ooids, } \\
\text { commonly quartz, skeletal } \\
\text { components } \\
\text { cements; isopachous fringes, } \\
\text { microspar, (sub)euhedral } \\
\text { dolomite crystals }\end{array}$ & $\begin{array}{l}\text { - Phi: } 10-15 \%, \\
\text { - Kh }=0.0001 \text { to } 2.5 \mathrm{mD} \\
\text { - Phi type: interparticle to } \\
\text { intercrystalline }\end{array}$ & $\begin{array}{l}\text { - background sedimentation with } \\
\text { frequent backshoal washovers, } \\
\text { algal lamination } \\
\text { - shallow sub aquatic } \\
\text { - normal sea water } \\
\text { - clastic influenced lagoon }\end{array}$ \\
\hline $\begin{array}{l}\text { Facies 6: Heterolithic } \\
\text { mudstones to wakestones }\end{array}$ & $\begin{array}{l}\text { - light to purple gray dolomites } \\
\text { - } 15 \mathrm{~cm} \text { to } 36 \mathrm{~cm} \text { average } 20 \mathrm{~cm} \text { thick } \\
\text { - graded mm-scale graded beds, teepees, } \\
\text { mudcracks, displacive anhydrite nodules, } \\
\text { - no bioturbation } \\
\text { - below: facies } 5 \text {; above: } 5,1,3\end{array}$ & $\begin{array}{l}\text { - components; peloids, quartz, } \\
\text { - cements; microspar, } \\
\text { subeuhedral dolomite crystals }\end{array}$ & $\begin{array}{l}\text { - Phi: } 5.8-10 \% \text {, } \\
\text { - Kh }=0.0001 \text { to } 0.01 \mathrm{mD} \\
\text { - Phi type: minor } \\
\text { intercrystalline }\end{array}$ & $\begin{array}{l}\text { - quiet water, algal lamination with } \\
\text { backshoal washovers, } \\
\text { - shallow subaquatic to subaerial } \\
\text { - super saturated sea water } \\
\text { - lagoon to sabkha transition }\end{array}$ \\
\hline
\end{tabular}

Fig. 6. Facies, sedimentary structures and microfacies of backshoal, lagoonal and sabkha deposits of the Upper Muschelkalk deposits in NE Netherlands identified in cores of the Knappersveld field. 


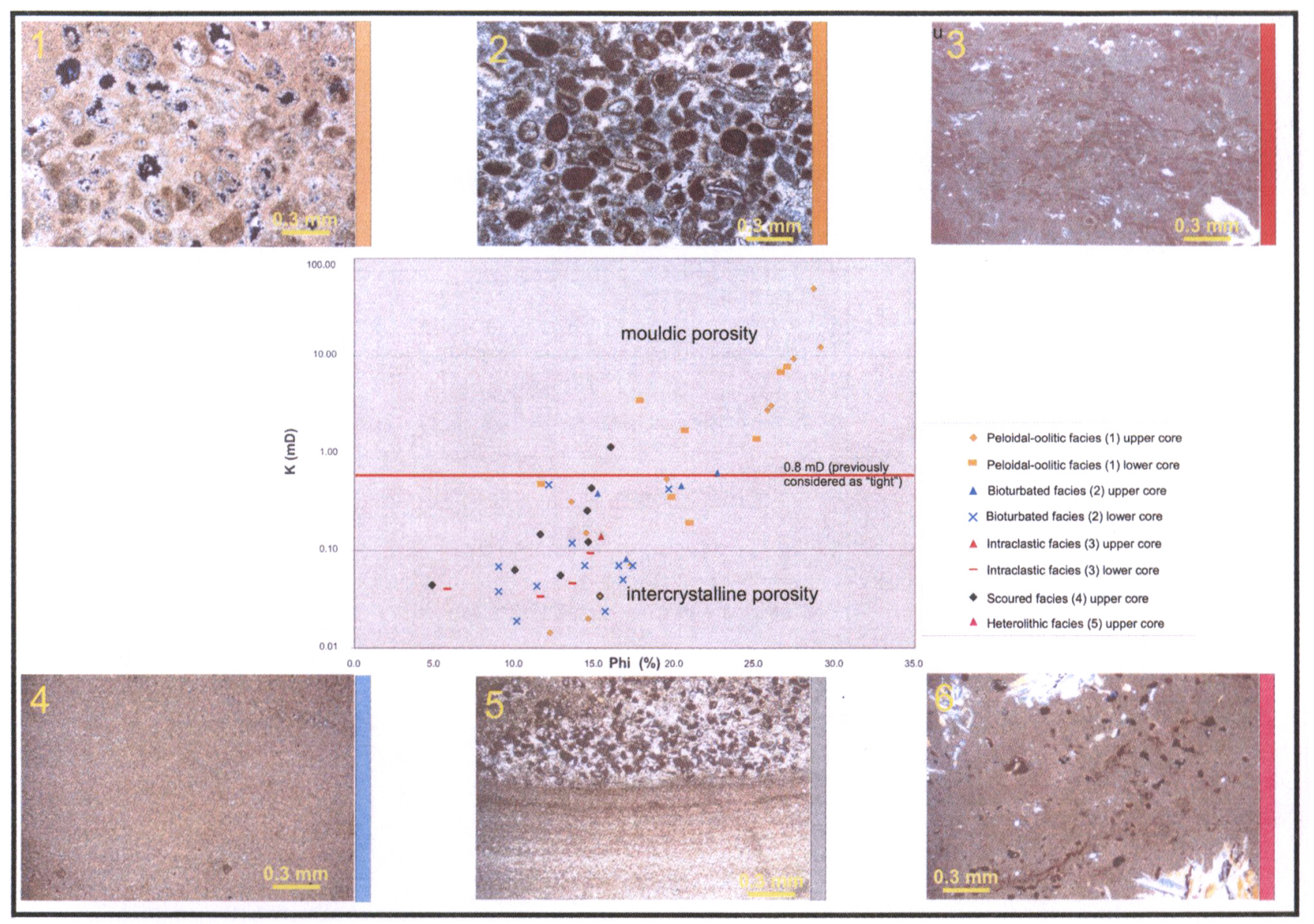

Fig. 7. Microfacies and associated reservoir properties of the Upper Muschelkalk. The best reservoir quality is encountered in thin regressive oolitic-peloidal grainstones to packstones.

deposits. Facies 2 is characterised by intense bioturbation of marine ichnofabrics leading to partial or complete destruction of sedimentary structures.
Relics of graded beds and oscillation ripples occur (Fig. 5.3). Facies 2 is interpreted as low-energy lagoonal deposits. Facies 4 and 5 show algal lamina-
Fig. 8. Pore types and paragenetic sequence of the Upper Muschelkalk carbonates. Permeability is in general poor due to the dominance of microporosity and separate moulds.

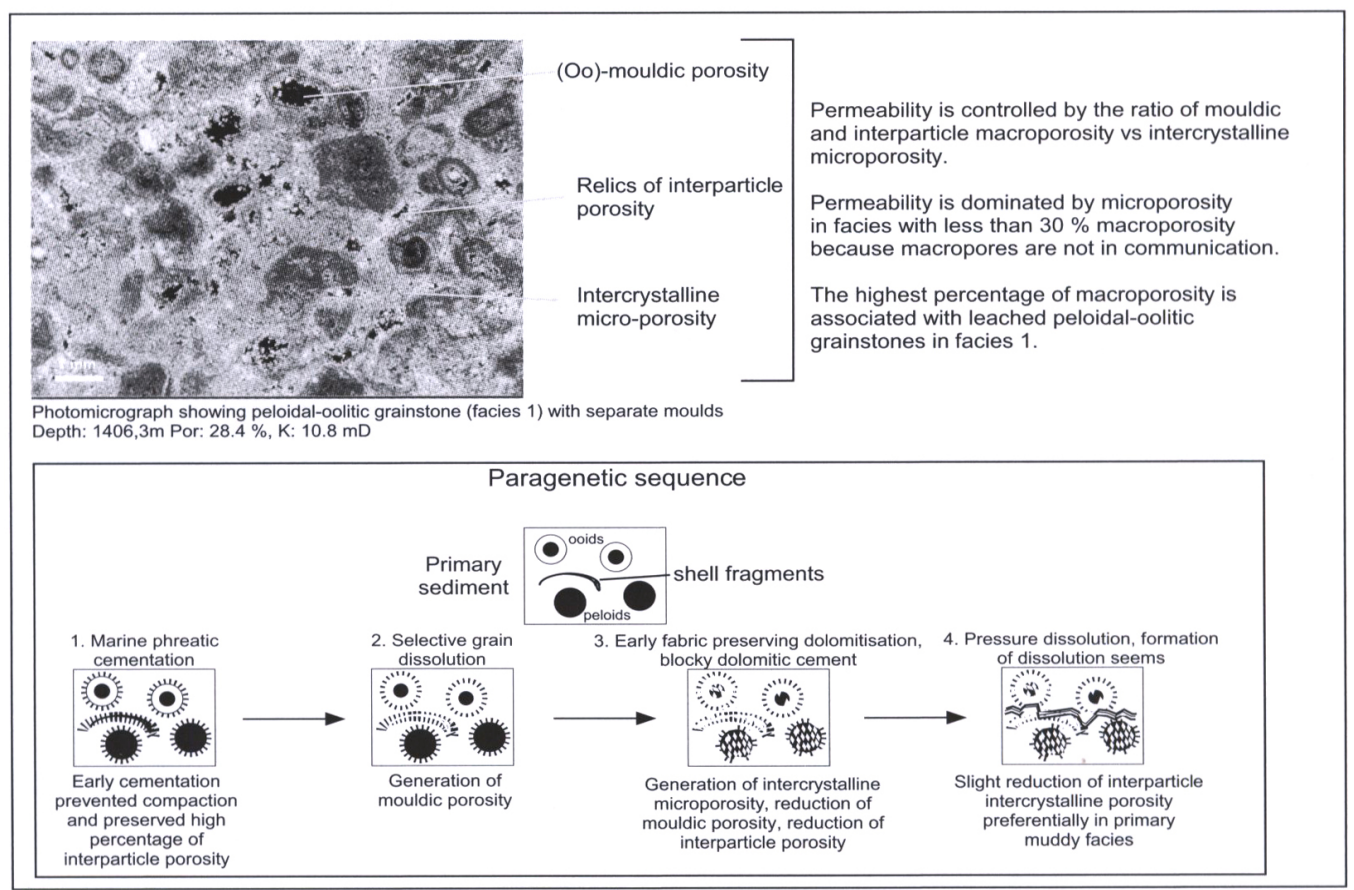




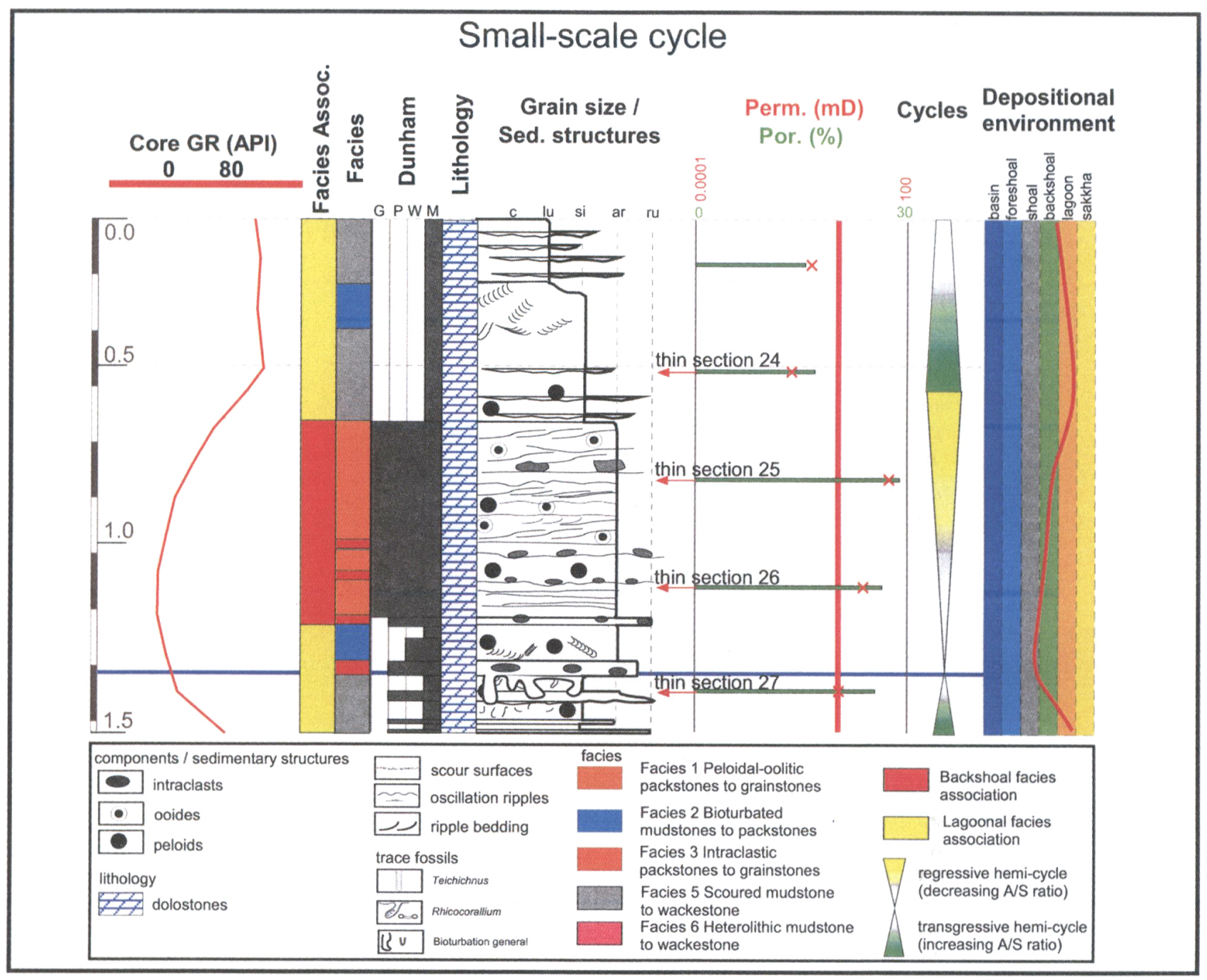

Fig. 9. Small-scale transgressive-regressive cycle and its expression on a GR log. These cycles are the smallest correlatable stratigraphic units. The Upper Muschelkalk in the NE Netherlands is composed of 24 of those cycles.

tion, thin graded beds, displacive anhydrite nodules and mud cracks (Figs 5.5 and 5.6). Graded beds testify rare storm influence in an overall quiet environment with hypersalinity and subaerial exposure.

The deposits are interpreted as low-energy lagoonal to sabkha environments (Fig. 6, 7). Thickness of facies 4 and 5 varies from centimeters to maximum several decimeters, with an average of $0.15 \mathrm{~m}$. The thinbedded nature made it impossible to apply an electrofacies scheme utilising the available open hole logs for facies recognition. The best reservoir quality is encountered in Facies 1 (peloidal-oolitic packstones to grainstones). It is the only facies with the bulk of permeabilities above $1 \mathrm{mD}$ (Fig. 7). Facies 1 contains significant oomouldic porosity, while all other facies are dominated by intercrystalline microporosity. The poorest poroperm characteristics are met in Facies 5 (heterolithic mudstones to wackestones).

Lithofacies, however, are only a first indication for reservoir quality. Individual facies show a wide scatter especially in permeability that is particularly apparent in Facies 1 (Fig. 7). This scatter is related to pore-type variations, which in turn are related to the percentage of leached components and early cementation. Commonly leached components are ooids and rare shell fragments. Unleached components are peloids, intraclasts and detrital grains (Figs 7,8).

Facies 1 shows good permeability if components are dominated by ooids and skeletal components, which turned into oomoldic and biomoldic porosity (Figs 7,8). Low permeability is encountered in Facies 1 if components are dominated by peloids, which create no mouldic porosity. Peloidal packstones and grainstones, especially in the lower part of the Upper Muschelkalk, are less well cemented and more compacted what reduces the percentage of interparticle porosity. Different pore types however cannot be inferred using the available open hole logs because of the limited vertical thickness of the individual facies. 


\section{Facies associations}

The five facies are grouped into two facies associations (Fig. 9) to allow core to open hole log calibration. These associations are defined based on core and openhole log character:

i) Facies association 1, backshoal association, comprising facies 1 and 3, $\Phi=10-29 \%, \mathrm{Kh}=0.05 \mathrm{mD}$ to $51 \mathrm{mD}$.

ii) Facies association 2, lagoonal/sabkha association, comprising of facies 2,4 and 5, $\Phi=5-22 \%, \mathrm{Kh}=$ $0.021 \mathrm{mD}$ to $2.5 \mathrm{mD}$.

Broadly speaking facies association 1 includes rocks with permeabilities above $1 \mathrm{mD}$ and facies association 2 rocks with permeabilities below $1 \mathrm{mD}$.

Facies association 1 varies in thickness between 0.6 $\mathrm{m}$ and $1.5 \mathrm{~m}$, while facies associations 2 is $0.6 \mathrm{~m}$ to $2.6 \mathrm{~m}$ thick. Facies associations, in contrast to single facies, can be identified on open hole logs. The backshoal association is represented by a combination of low gamma ray and low density readings and in places slow sonic velocities. The lagoonal / sabkha association can be identified by high gamma ray and high density readings. An attempt was made to automate this facies association's identification from open hole logs by means of a statistical tool. However, absolute readings of open hole logs are too variable, thus proving insufficient for this purpose. Hence facies associations were identified qualitatively from logs.

Results were used to identify better quality sections outside of cored intervals and to support rock property characterization.

\section{Cyclicity}

Three hierarchical levels of cycles are interpreted from cores and open hole logs:

i) Small-scale cycles: 1.5 to $3.0 \mathrm{~m}$ thick (might represent $6^{\text {th }}$ order cycles)

ii) Medium scale cycles: 8 to $12 \mathrm{~m}$ thick (might represent $5^{\text {th }}$ order cycles)

iii) Large scale cycles: 35 to $50 \mathrm{~m}$ thick (might represent $4^{\text {th }}$ order cycles)

\section{Approach}

Core descriptions clearly showed facies and facies associations are vertically stacked into small-scale cycles. Subdivision of these cycles is based on inferred changes in the ratio of accommodation (A) versus supply (S) derived from facies characteristics, grain types and fossils. Cycles consist of two hemi-cycles; the transgressive hemi-cycle represents increasing A/S ratio and the regressive hemi-cycle represents decreasing $\mathrm{A} / \mathrm{S}$ ratio.

\section{Small-scale cycles}

A typical facies succession, 1 to $3 \mathrm{~m}$ thick (Fig. 9), begins with intraclasts packstones and grainstones containing numerous firmgrounds and bored intraclasts. These pass into peloidal-oolitic packstones to grainstones (Facies 1) with omnipresent erosive contacts like scour surfaces (Facies 1). These give way to bioturbated mudstones and packstones (Facies 2). Higher up, in core 2, Facies 1 passes rapidly into argillaceous scoured and heterolithic mudstones and grainstones (Facies 4, 5) with significant amounts of clastic debris.

This typical facies succession is interpreted in terms of changes of accommodation (A) versus supply (S) ratio. Intraclast packstones and grainstones (Facies 3) represent maximum A/S ratio, testified by maximum grain size (intraclasts), which point to high-energy conditions and numerous firmgrounds. They are interpreted as zone of maximum transgression. The overlying peloidal-oolitic packstones and grainstones (Facies 1) represent decreasing A/S ratio as shown by numerous erosive contacts and strong amalgamation of the grainy sediments. Minimum A/S ratio is interpreted at the top of facies 1 or at the top of the overlying argillaceous scoured and heterolithic mudstones to wackestones (facies 4,5 ), in the higher part of the succession. Strong amalgamation, subaerial exposure and an elevated clastic content points to maximum regression linked with progradation of clastic material i.e. filled accommodation space.

The overlying bioturbated packstones to mudstones (Facies 2) show an increasing A/S ratio. This is indicated by well-preserved marine ichnofabrics and increasing sets thickness of intercalated graded beds. They are interpreted as transgressive hemi-cycle.

In terms of reservoir quality these cycles show a clear dual subdivision. The cycle base is dominated by backshoal facies with high reservoir potential, which pass upward into muddy facies with poor reservoir quality (Fig. 9). Cycles are easily to recognise on open hole logs, particularly in the upper part of the reservoir (Fig. 10). The clean, grainy lower part of a cycle is reflected by low gamma ray and low density, in sometimes slow sonic readings. The dirty, muddy upper part shows higher gamma ray, higher density and often faster sonic values. Care should be taken to rely on gamma ray logs alone. Very low gamma ray readings in the lower part of the Upper Muschelkalk, which are not accompanied by low density or sonic values, represent clean, but tight carbonates.

The $50 \mathrm{~m}$ thick Upper Muschelkalk succession consists of twenty-four small-scale cycles (Fig. 10), which represent the smallest correlatable stratigraphic unit. The cycles are correlatable across the Coevorden 


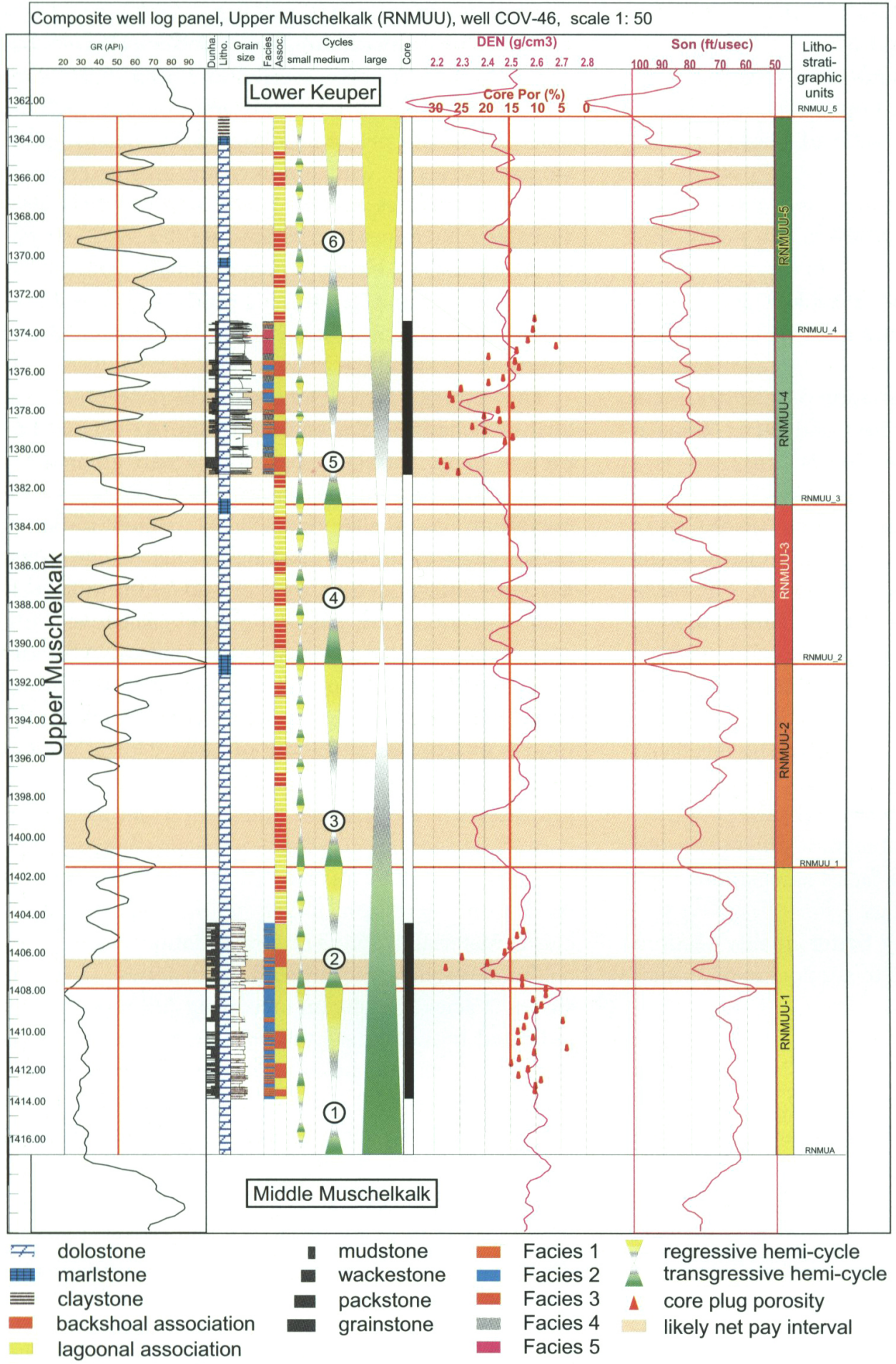

Fig. 10. Composite well log panel of the Upper Muschelkalk showing core facies and its expression on open hole logs.

Muschelkalk field. The lateral continuity of these cycles on field-scale, suggests that facies associations are sheet-like extended over distance of at least several hundreds of meters. This assumption is supported by outcrop observations in Southern Germany (Schauer \& Aigner, 1997) and outcrop analogue studies in Northern Germany (Borkhartaria, 2002). These studies show that small-scale cycles extend easily across outcrops, over distances of several hundreds of meters. Moreover seismic attribute maps did not show areal variations suggesting rather constant reservoir quality in the Coevorden Muschelkalk field (Hoetz et al., 2001).

\section{Medium-scale cycles}

Small-scale cycles are stacked into six medium-scale cycles (Fig. 10), each 6 to $12 \mathrm{~m}$ thick. These cycles show a characteristic cleaning up gamma ray trend followed by a dirtying up trend, similar to small-scale cycles. The limited core data suggest that the cleanest 
gamma ray signature corresponds to the highest percentage of peloidal-oolitic grainstones (Facies 1). In contrast maximum gamma radiation corresponds to muddy, argillaceous very low permeable facies. These meter thick muddy intervals likely act as vertical flow barriers, separating the reservoir into different flow units.

Genetically the bases of the clean intervals are interpreted as point of maximum transgression (maximum A/S ratio), while the dirtiest gamma ray signature reflects maximum regression (minimum $\mathrm{A} / \mathrm{S}$ ) (Fig. 10). Note that this is the reverse of a 'normal' marine sequence where maximum gamma ray often reflects maximum transgression.

The medium-scale cycles distinguished here are similar to the lithostratigraphic units proposed by Pipping, 1999 (Fig. 10) numbered from bottom to top: RNMUU-1 to RNMUU-5. The lowermost unit RNMUU-1 of Pipping, 1999 corresponds to our medium-scale cycles 1 and 2 (Fig. 10). The mediumscale cycles are correlatable in the NE Netherlands over more than $25 \mathrm{~km}$ (Pipping, 1999) and have been traced to outcrops in Northern Germany over distances of more than $150 \mathrm{~km}$ (Borkhartaria, 2002).
Their signature is comparable to cycles described from Northern Germany (Röhl, 1990 and Gärtner, 1993). Hence the medium-scale cycles are proposed as regional stratigraphic framework.

\section{Large-scale cycles}

Regional studies have shown the Upper Muschelkalk consists of one large-scale cycle, composed of a lower transgressive and an upper regressive hemi-cycle (Aigner, 1985, (Hagdorn et al., 1987, Röhl, 1990, Gärtner, 1993). Lack of a complete core and the apparent absence of bioclastic marker beds makes it difficult to exactly determine the extent of these two large-scale hemi-cycles. Preliminary the mediumscale cycles 1 to 3 are interpreted as lower transgressive hemi-cycle and the medium-scale cycles 4 to 6 are part of the regressive hemi-cycle (Fig. 10). Consequently the zone of maximum flooding is interpreted in the middle of medium-scale cycle 4 (Fig. 10). This interval, dominated by peloidal-oolitic packstones to grainstones, would be the lateral equivalent of the Terebratel bed, a widely developed marker beds in Germany (Hagdorn et al., 1987, Aigner \& Bachmann, 1992). The separation of lower and upper

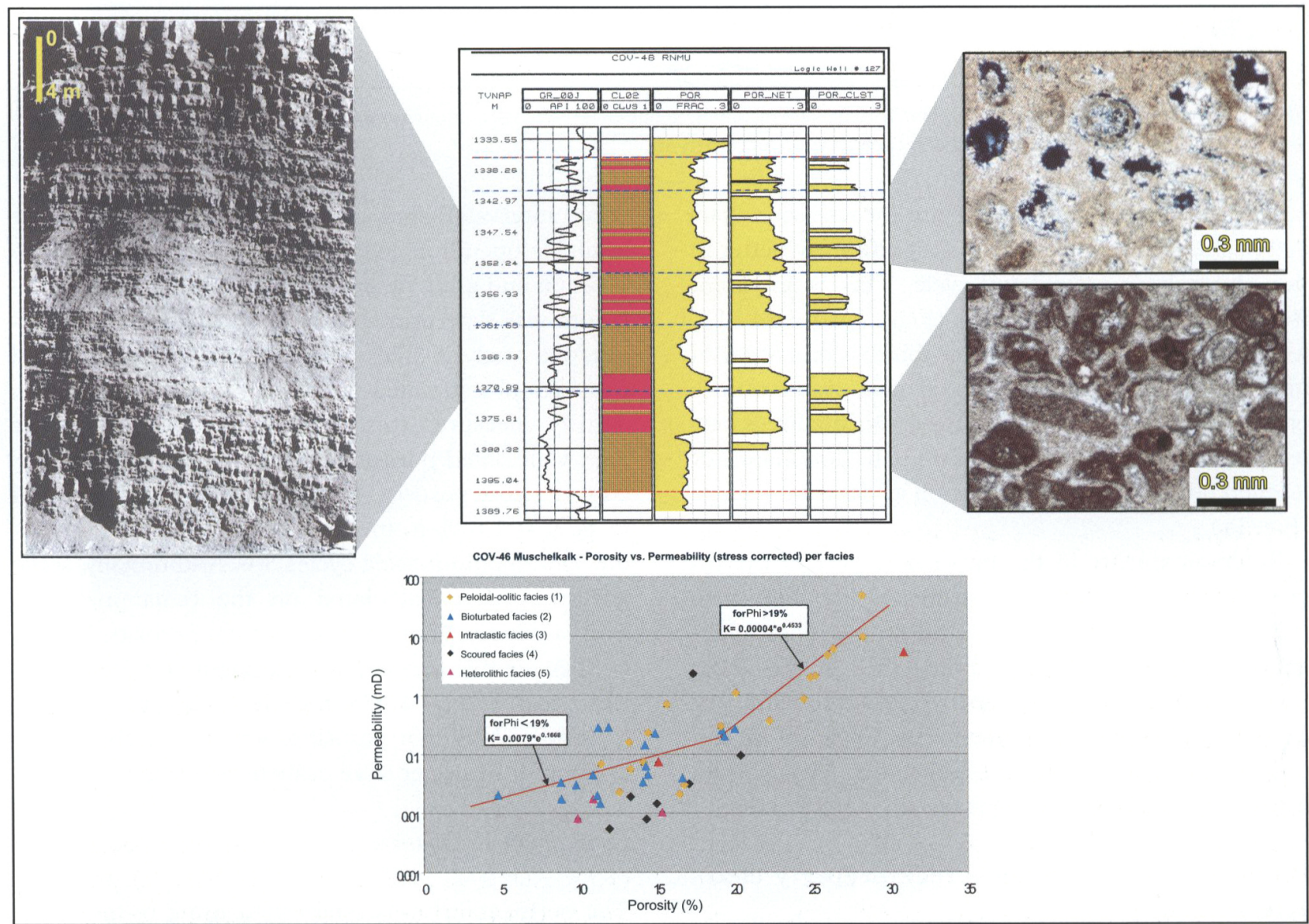

Fig. 11. Reservoir quality variations in the Upper Muschelkalk in outcrop, open hole log, and thin section scale and associated petrophysical evaluation. 


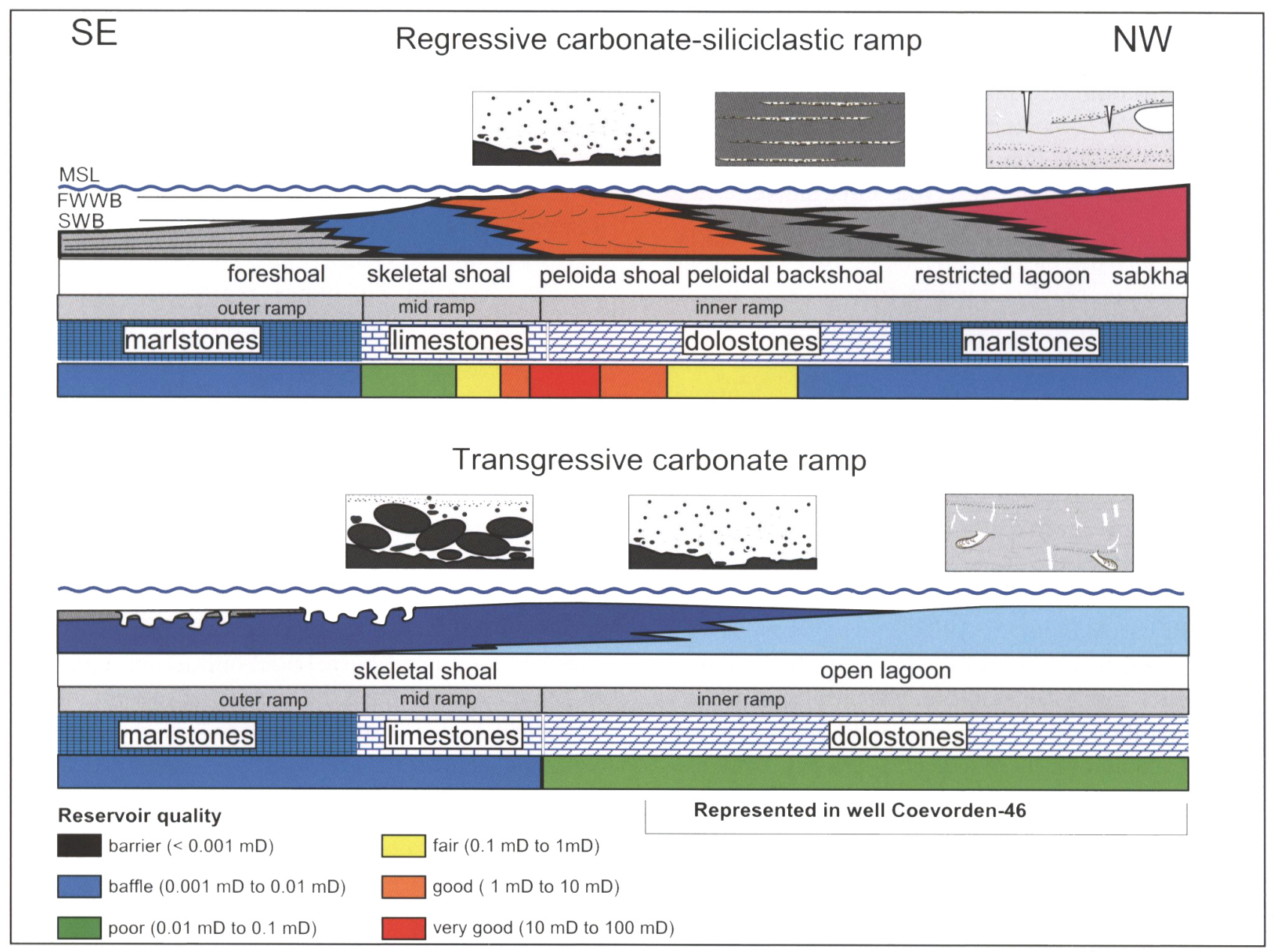

Fig. 12. Depositional model for the Upper Muschelkalk including major environments, sub-environments and their reservoir quality. Highlighted are the environments represented in cores of well Coevorden- 46.

large-scale hemi-cycle is important for reservoir characterization. Reservoir quality is significantly better in the upper large-scale hemi-cycle. This is apparent from core plugs measurements (Figs 7,10 ) and PLT $\log$ data, which show that permeability is one order of magnitude better in this interval and production is only coming from from there. Reservoir quality is better in the regressive hemi-cycles due to dominance of leached ooids and less compaction as described above (Fig. 11).

Reservoir quality in the uppermost part of the regressive hemi-cycle probably decreases (medium-scale cycle 6) due to increase in clastic supply. These finegrained clastics, coming from the north (e.g., Fennoscandian High) and west (e.g., London-Brabant Massif) gradually replace carbonates. Cycles of all levels are correlatable across the Coevorden Muschelkalk field suggesting layer-cake type reservoir architecture.

\section{Petrophysical evaluation - rock property char- acterisation}

Reservoir characteristics may be extrapolated to un- cored intervals based on formation evaluation of the available open hole logs (Fig. 11). Bulk mineral composition and grain density, as input for porosity calculation, was determined with an integrated statisticaliterative analysis. This analysis is based on mineral proportions estimated from thin sections, core grain density measurements and all available open hole logs. Calculated porosities were matched and validated using core porosity. The uncertainty was estimated to be $\mathrm{s}_{\mathrm{f}}=1.6 \%$ in medium-scale cycle $1-3$ and $\mathrm{s}_{\mathrm{f}}=$ $0.8 \%$ in medium-scale cycles 3-6. Additionally, sonic porosities were calculated on the remaining wells from a relation sonic porosities-total porosity. Uncertainties for this method are estimated at $3.5 \%$ in cycles 1 to 3 ; and $\mathrm{s}_{\mathrm{f}}=1.6 \%$ in cycle 4,5 and 6 .

Results show that porosities are comparable in the lower and the upper large-scale hemi-cycle.

\section{Permeability calculation}

The permeability was established using re-measured porosity and permeability data from core plugs measurements of well Coevorden- 46 . 
Two different porosity-permeability functions were defined for the two facies associations. One function was defined for facies association 2 and another function was established for the facies association 1 to honour their different pore types (Fig. 11).

Results confirm the presence of higher permeable rocks in the upper large-scale hemi-cycle.

\section{Depositional model}

Facies and vertical facies successions can be interpreted, together with regional knowledge, in terms of a depositional model (Fig. 12). The Upper Muschelkalk consists of storm-dominated peloidal-oolitic carbonate sands and bioturbated and algal laminated sediment with variable amount of clastic debris. The succession is very poor in body fossils only a few shell fragments occur. These deposits are interbedded and gradually pass into each other in a cyclic fashion.

The coexistence of carbonate sand and lagoonal sediments suggest the existence of some sort of morphological differentiation along the depositional gradient in shoal and lagoon, which is temporally subaerially exposed. This section represents the inner part of a storm-dominated homoclinal ramp (Fig. 12) The low thickness of carbonate sands, $(10$ to $30 \mathrm{~cm}$ ), strong amalgamation and rapid vertical facies changes might point to slow subsidence. Critical for reservoir development is the presence of backshoal deposits. Its distribution is currently poorly understood.

\section{Sequence stratigraphic model}

The Upper Muschelkalk deposits show a strong hierarchical cyclicity, which is important for reservoir quality prediction. On a large scale the Upper Muschelkalk occupies the interval between shallow marine evaporates below and shallow marine to coastal plain clastics above. Clean carbonates are present mainly in the lower transgressive hemi-cycle. Maximum transgression corresponds with thick peloidal-oolitic packstones and grainstones. Siliciclastic influx continuously increases during the upper regressive hemi-cycle finally leading to termination of carbonate production and deposition of claystones. Large-scale cyclicity also causes better permeable beds and the entire gas production to occur only in

Fig. 13. Stratigraphic correlation of the Upper Muschelkalk in the Coevorden Muschelkalk field. Medium-scale cycles and small-scale cycles are well correlatable on field-scale. Note medium-scale cycle 3 is faulted out in well Coevorden-29. However the well has the only available PLT log, which shows production coming only (from the un-faulted) medium-scale cycles 4 and 5.

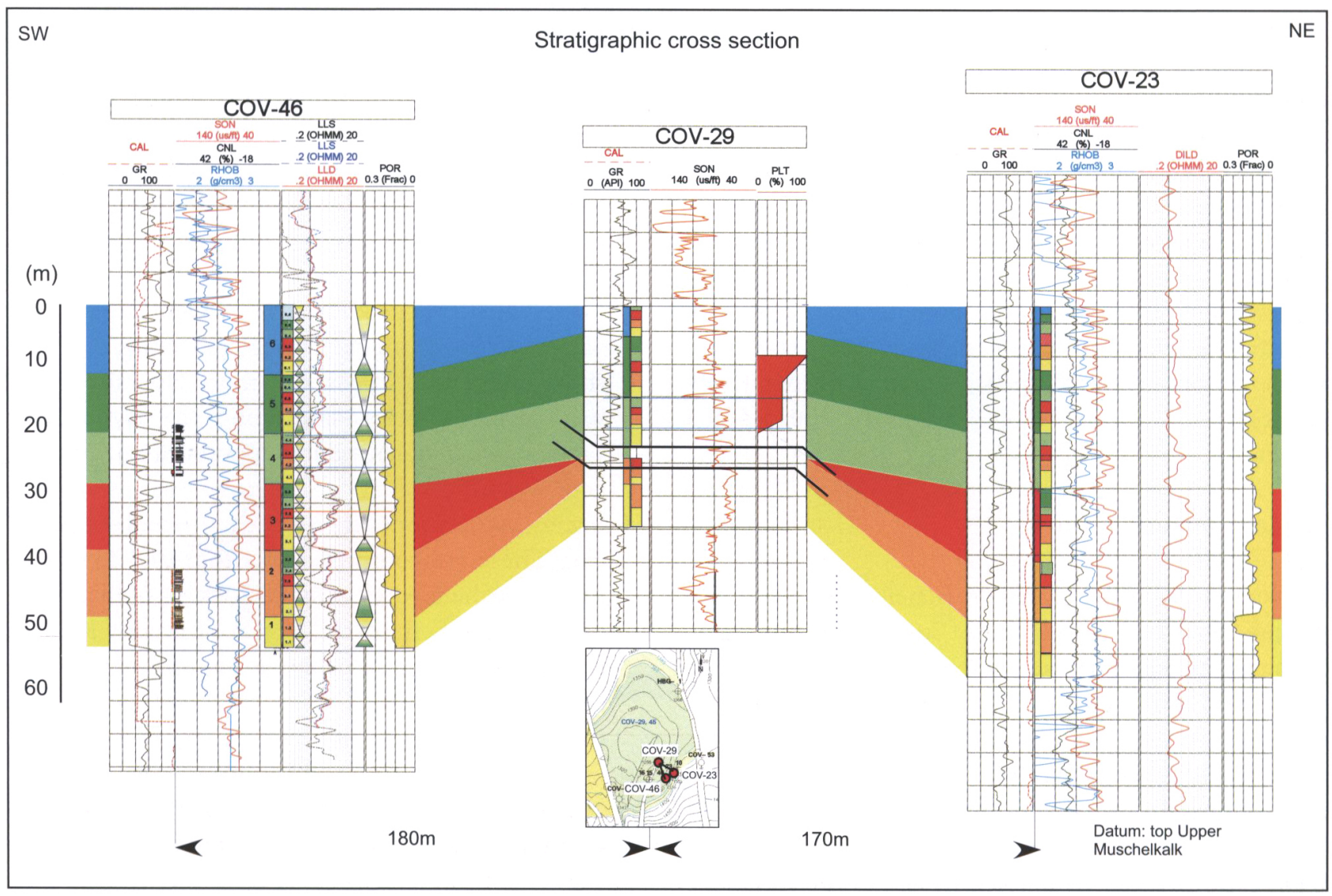


the upper large-scale regressive hemi-cycle (Fig. 13). The improved reservoir quality is due to a higher percentage of leached ooids and stronger early diagenetic cementation causing grain armouring against compaction (Fig. 11).

Medium scales cycle reflect lateral shift of facies belts as suggested by the correspondence of change in carbonate facies and percentage of clastic deposits. Beginning transgressions leads to production of muddy carbonates. Seawater influx is suggested by the presence of marine ichnofabrics. Carbonate sand bodies, if present at all, are thin and gradually shift landwards. Peak transgression is associated with maximum water depth leading to formation of intraclasts, which are reworked and bio-eroded. Thin ooliticpeloidal carbonate sands form during beginning regression. At the same time clastic deposits prograde from paleohighs such as the Fennoscandian High and the London Brabant Massif. During peak regressions the carbonate sands are briefly subaerially exposed or argillaceous carbonates might be deposited.

These observations suggest a clear facies differentiation. Muddy, lagoonal deposits are predominantly deposited and preserved during transgression while they are rare during regressions. Grainstones occur preferentially after peak transgression and during beginning regression (Fig. 12).

Small-scale cycles, might be the result of local autocyclic shifts of shoal and lagoon or caused by allocyclic controls such as fluctuating influx of sea-water.

Outcrop analogue studies have confirmed that cyclicity is an important control on reservoir quality (Braun, 2000). Carbonates formed during the transgressive hemi-cycle are composed of a higher percentage of muddy carbonates with lower reservoir potential. In contrast carbonates deposited during overall regressive interval are component rich and show a higher reservoir potential. Additionally the likelihood of subaerially exposure and leaching, key pre-requisite for reservoir development, is greater during overall regression (Braun, 2000; Kostnik, 2001, Ruf, 2001).

\section{Discussion and outlook}

Production from the Upper Muschelkalk is currently unique in the Netherlands in the Coevorden Muschelkalk field. However the present investigations show that reservoir quality is not related to unique local geological conditions but to dolomitic shoal facies, which is likely developed over a much larger area. Detailed facies maps from Southern Germany suggest the dolomitic shoal area extends for at least tens of kilometres. Key pre-requisite to target success- ful Muschelkalk wells is the generation of maps from the grainstone facies belt and knowledge of the gross lithology. Furthermore it is important to find structures with preserved upper regressive hemi-cycle, with significantly better reservoir quality, with might be the only producing unit (Fig. 13).

This study is part of an ongoing regional evaluation of reservoir potential of the Upper and Lower Muschelkalk in the Netherlands. This effort aims on extending the stratigraphic framework from the NE Netherlands to key wells in the Netherlands and generation of play maps. Maps are generated using cuttings, openhole log data and seismic sections. This work is accompanied by quantitative facies description in outcrops with the objective to generate data on reservoir body geometries and rules to locate reservoir sweet spots.

\section{Conclusions}

1.The Upper Muschelkalk in the NE-Netherlands can be subdivided into five facies. These have been interpreted as backshoal, lagoonal and sabkha deposits forming the inner part of a storm-dominated carbonate ramp.

2. Facies show distinct differences in reservoir quality. Good reservoir quality is associated with grain-rich facies (Facies 1,3) while poorer reservoir quality is found in muddier facies types (Facies 2, 4, 5). Facies are in average 0.1 to $0.4 \mathrm{~m}$ thick.

3. Facies 1 is composed of grainstones to mud-dominated packstones with mouldic, interparticle and intercrystalline porosities. Variability in amount of moulds accounts for the observed permeability variations. All other facies are composed of muddominated packstones to mudstones mainly with intercrystalline microporosity.

4. Facies are arranged into two facies associations, each 1 to $2.6 \mathrm{~m}$ thick. Facies association 1 (backshoal association), possesses more favorable reservoir quality. Facies association 2, (lagoonal to sabkha association), exhibits poorer reservoir characteristics.

5. Facies associations are stacked to small-scale cycles. These are comprised of a thin ( 0.3 to $0.8 \mathrm{~m})$ regressive hemi-cycle and a thick ( 1.5 to $2.0 \mathrm{~m}$ ) transgressive hemi-cycle. Reservoir quality is better in the lower regressive than in the upper transgressive part. These small-scale cycles are the smallest correlatable stratigraphic units.

6. Small-scale cycles are stacked into 5 medium-scale cycles, each 8 to $12 \mathrm{~m}$ thick. These are the basis for the regional stratigraphic framework.

7. The succession is part of a large-scale cycle. This 
consists of a lower transgressive hemi-cycle, $30 \mathrm{~m}$ thick and an upper regressive hemi-cycle, about 20 $m$ thick. The upper hemi-cycle shows significantly better reservoir quality than the lower transgressive hemi-cycle.

8. Interwell stratigraphic correlations and outcrop analogue work demonstrated that the Upper Muschelkalk reservoir could be treated as a layercake reservoir at field scale.

\section{Acknowledgements}

Thanks are due to K. Pipping, NAM, M. Geluk, NAM and T. Aigner, Tübingen University for sharing their knowledge on the Upper Muschelkalk. Many thanks to J. Penniga and G. De Rink, NAM for assistance with preparation of core slabs and core photographs. Ch. Elliot, NAM and V. Hitchings, SEPTAR are gratefully acknowledged for helpful comments on previous versions of the manuscript.

The manuscript benefited greatly from the reviews by $M$. Geluk, J. Lutgert and $H$. Mijnlieff. We thank NAM for the permission to publish this paper.

\section{References}

Aigner, T., 1985. Storm depositional systems. Dynamic stratigraphy in modern and ancient shallow marine sequences. Lecturer Notes in Earth Science 3. Springer Verlag, (Berlin): 174 pp.

Aigner, T. \& Bachmann, G.H., 1992 Sequence stratigraphic framework of the German Triassic. Sedimentary Geology 80: 115-135.

Borkhataria, R., 2002. Reservoir model for the Upper Muschelkalk of the Coevorden field and the NE Netherlands. Unpublished extramural research project module $B: 1-35$.

Braun, S., 2000. Quantitative analysis of carbonate sandbodies: outcrop analog study from an epicontinental basin (Triassic, Germany). Unpublished extramural research project CP 00621 . Shell International Exploration and Production (The Hague): 1-53.

Choquette, P.W. \& Pray, L.C., 1970. Geologic nomenclature and classification of porosity in carbonates. Bulletin of the American Association of Petroleum Geologists 54: 207-250.

Dercourt, J., L.E. Ricou \& B. Wrielynck (eds), 1993. Atlas Tethys Paleoenvironmental maps. Gauthier-Villars (Paris): 135 pp.

Duchrow, H., 1984. Der Keuper im Osnabrücker Bergland. Mit einer Revision der Nordwestdeutschen Trias-Gliederung. In: Klassen, H. (Ed.) Geologie des Osnabrücker Berglandes. Naturwissenschaftliches Museum, Osnabrück: 221-333.

Dunham, R.J., 1962. Classification of carbonate rocks according to depositional texture. Memoirs of the American Association of Petroleum Geologists 1: 108-121.

Gärtner, H., 1993. Zur Gliederung des Muschelkalks in Nordwestdeutschland anhand von Bohrlochmessungen. In: Hagdorn, H. \& Seilacher, A. (eds) Muschelkalk. Schöntaler Symposium 1991. Sonderbände der Gesellschaft für Naturkunde in Württemberg 2: 183 pp.

Hagdorn, H., Hickethier, H., Horn, M. \& Simon, T., 1987. Profile durch den hessischen, unterfränkischen und baden-württembergischen Muschelkalk. Geologisches Jahrbuch Hessen 115: 131-160.
Hoetz, G., Pöppelreiter, M., den Bezemer, T. \& Simone, A., 2001. Knappersveld -Coevorden Muschelkalk- field development plan. Unpublished NAM report 200201000793: 18 pp.

Kerans, C. \& Ticker, S., 1997. Sequence stratigraphy and characterisation of carbonate reservoirs. Society of Economic Petrologists and Minerologists Short Course No. 40 (Tulsa): 130 pp.

Kostnic, B., 2001. Sedimentäre Strukturen, Fazies und PoropermEigenschaften in ausgewählten "Karbonatsanden": Quaderkalk, Oberer Muschelkalk. MSc thesis. (University of Tübingen): 86 pp.

Lucia, F.J., 1999. Carbonate reservoir characterization. Springer Verlag (Berlin): $226 \mathrm{pp}$.

Lucia, F.J., Jennings, J.W. Jr., Rahnis, M. \& Meyer, F.O., 2001. Permeability and rock fabric from wireline logs, Arab-D reservoir, Ghawar field, Saudi Arabia. GeoArabia 6(4): 619-646.

Mabillard, J.E., v.d. Baan, D., Speksnijder, A., Bloch, G. \& Kuilman, L., 1989. The regional geology of the Germanic Triassic. Unpublished NAM report 19.088: 164 pp.

Marsaglia, K.M. \& de Vries Klein, G. 1983. The palaeogeography of Palaeozoic and Mesozoic storm depositional systems. Journal of Geology 91: 117-142.

Pipping, C.J.E., 1999. Subdivision of the Upper Muschelkalk (Middle Triassic, Anisian) in the Coevorden field and the northeastern part of the Netherlands. Unpublished NAM report 199906000460: $54 \mathrm{pp}$.

Pöppelreiter, M., 2001. Reservoir geological review of the Upper Muschelkalk carbonates in the Coevorden field. Unpublished NAM report 200106000958: $11 \mathrm{pp.}$

Röhl, U., 1990. Parallelisierung des norddeutschen oberen Muschelkalks mit dem süddeutschen Hauptmuschelkalk anhand von Sedimentationszyklen. Geologische Rundschau 79(1): 1326.

Ruf, M., 2001. Facies distribution, petrophysics and mapping of selected carbonate sand bodies in the Upper Muschelkalk, South German basin: A reservoir analogue investigation. MSc thesis. (University of Tübingen): $106 \mathrm{pp}$.

Schauer, M. \& Aigner, T., 1997. Cycle stacking pattern, diagenesis and reservoir geology of peritidal dolostones, TrigonodusDolomit, Upper Muschelkalk (Middle Triassic, SW-Germany). Facies 37: 99-114.

Simone, A., 2001. Coevorden Knappersveld area - Upper Muschelkalk Petrophysical Review. Unpublished NAM report 200104100735: $22 \mathrm{pp}$.

Sonnenfeld, M.D. \& Cross, T.A., 1993 Volumetric partitioning and facies differentiation within the Permian Upper San Andres Formation of the Last Chance canyon, Guadalupe Mountains, New Mexico. In: Lounks, R.G. \& J.F. Sarg (eds) Carbonate sequence stratigraphy: Recent developments \& Applications. American Association of Petroleum Geologists Memoir 57: 435-474.

Szulc, J., 1999. Anisian-Carnian evolution of the Germanic basin and its eustatic, tectonic and climatic controls. In: Bachmann, G. \& I. Lerche (Eds) Epicontinental Triassic. Zentralblatt für Geologie and Paläontologie 1(7-8): 813-852.

Van Adrichem Boogaert, H.A. \& Kouwe, W.F.P., 1993. Stratigraphic nomenclature of the Netherlands, revision and update by RGD and NOGEPA. Medelingen Rijks Geologische Dienst 50: 1-23.

Wright, V.P., 1992. A revised classification of limestones. Sedimentary Geology 76: 177-185.

Ziegler, P.A., 1990. Geological Atlas of Western and Central Europe. Shell International Petroleum Maatschappij B.V. (Amsterdam): $238 \mathrm{pp}$. 